\title{
Galba truncatula (Gastropoda, Lymnaeidae): effects of daily water- level variations on the ecology and ethology of populations living upstream from a dam
}

\author{
P. Hourdin, P. Vignoles, G. Dreyfuss, D. Rondelaud* \\ UPRES EA n 3174 / USC INRA, Facultés de Pharmacie et de Médecine, 87025 Limoges, France
}

Field investigations in two lymnaeid habitats located along river banks were carried out over three years to study snail colonization in relation to water-level variations, to determine the number of annual generations, and to analyse the ability of G. truncatula to emerge from water. As these river banks were located $6.7 \mathrm{~km}$ upstream from a dam, water recedes each day, thus permitting the study of snails on banks for several hours per day. From March to December, snails followed seasonal variations of water-level. However, only a few G. truncatula were observed following the daily retreat of water. Two annual generations of G. truncatula, the first from the onset of July and the second in December, were noted in these habitats. When water receded each day, the mean distance covered by non-aestivating snails ranged from 25 to $44 \mathrm{~cm}$. However, they escaped water rise by seeking refuge in still emerged zones of their habitats. From July to October, snails following each day water receding showed a significantly quicker growth than that of $G$. truncatula which only moved in the same zone of their habitat. Populations of $G$. truncatula living along these river banks would be completely adapted to their habitat. The escape of snails from water rise between July and October might correspond to a physiological reaction of survival when a too rapid increase of water-level occurs.

Keywords: acid soils, ecology, ethology, Galba truncatula, Limousin, river banks.

\section{Introduction}

Dams are known for many years to have effects on biological stability in wetlands so that river and floodplain ecosystems are closely adapted to a river's flooding cycle. The native plants and animals depend on their variations for their reproduction, hatching, migration, and other important life-cycle stages. The most severely impacted invertebrate communities are those of benthic species, as the reduced current in the rivers located upstream from dams causes increased deposition of sediments, thus creating poor habitats for bottom-dwelling organisms (Burt \& Watts 1996). Another less studied effect is due to water-level variations in dams. Indeed, winter floods of upstream rivers and the demand for water by people during the warmer months induce seasonal variations of waterlevel which are especially important in summer. When the water of a dam is also used to produce electric energy, daily variations of water-level, even in upstream rivers, can be observed (Burt \& Watts 1996). This seasonal and/or daily hydrodynamics in upstream rivers create more favourable conditions for communities of freshwater pulmonates which are living on river banks. Indeed, in rivers of central France located upstream from dams, the habitats of the snail Galba truncatula (O.F. Müller) were numerous, with high snail densities (Rondelaud unpublished results). In contrast, when the rivers did not flow into a dam, snail habitats were scarce and populations of G. truncatula comprised low numbers of snails (Dreyfuss et al. 1997).

In view of this last finding, one may wonder whether water-level wariations in upstream rivers did not have an impact on the ecology of the snail. Indeed, in several rivers of the Limousin region, central France (without dams), Vareille-Morel et al. (1998) found a single annual generation for $G$. truncatula, with egg-laying at mid-July and the development of juvenile snails on emerged banks from August to September. As no study was performed on the ecology of freshwater pulmonate communities living in rivers subjected to daily water-level variations, the three aims of the present study were i) to determine the precise number of annual generations for these G. truncatula, ii) to analyse their numerical fluctuations throughout the year, and iii) to specify the zones of the habitats which are colonized by snails in relation to water-level. Fortnightly investigations were thus carried out over three years (2001-2003) in two habitats of G. truncatula located upstream from a dam.

*Corresponding author: E-mail: daniel.rondelaud@unilim.fr 


\section{Sampling sites}

The two populations of $G$. truncatula (Fig. 1) were living in the commune of Saint Priest Taurion, department of Haute Vienne (central France). The first inhabited a 35-m long area (site A) on the right bank of the Vienne river, while the second community colonized a 30-m long section (site B) on the right bank of the Taurion river, at the bottom of the bridge which spanned it. The two banks were located $6.7 \mathrm{~km}$ upstream from the dam of Palais sur Vienne (Fig. 1).

In each habitat, five zones (Fig. 2) were observed. The highest (Z1) was constituted by bare ground (the bank of the Vienne river) or was covered with Dactylis glomerata (Poaceae) among several granite rocks (that of the Taurion river). The top part of the slope (Z2) was colonized by Glyceria fluitans (Poaceae). The lower part of the Z2 zone and the Z3 section (without macrophytes) were covered with a silty sediment. The lowest two zones (Z4 and Z5) corresponded to the bed of the river and were constituted by sand and granite, respectively. They were covered in places with pebbles and gravelly, silty sand.

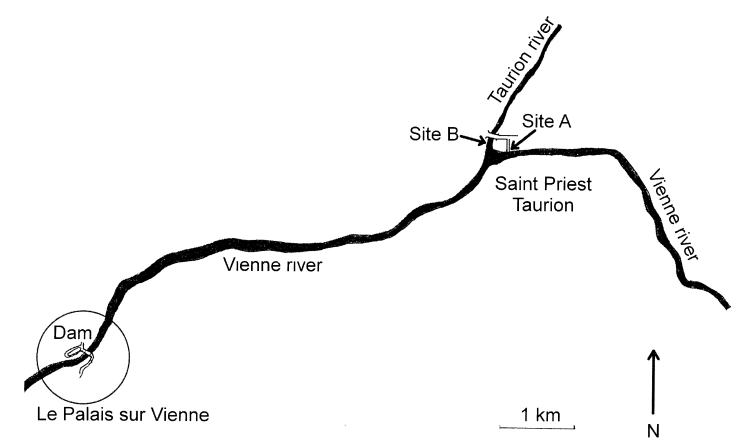

Fig. 1. Map showing the rivers and the dam including distances from dam to studied sites.

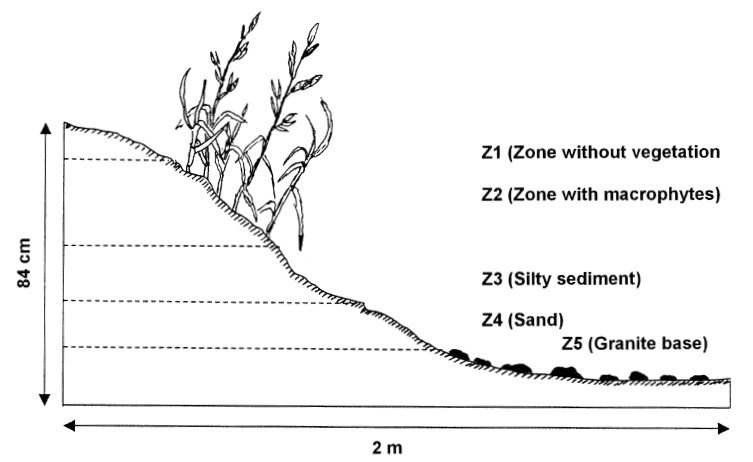

Fig. 2. Transect showing the five zones (Z1 to Z5) on the bank of the Vienne river at Saint Priest Taurion.

\section{Methods}

\section{Water-level variations throughout the year}

Fortnightly records at 4 p.m. were done from 2001 to 2003 to determine water-level variations on the right bank of the Vienne river. Four parameters were measured: the height of water layer at the lowest point of the Z5 zone, the height of the emerged zone, the width of the submerged bank (measured from the lowest point of Z5 zone), and the width of the emerged zone. The values recorded during the three years were pooled before being averaged and S.D. established.

\section{Distribution of snails in their habitat throughout the year}

Fortnightly investigations were carried out from March to December during the three years. No observation was performed in January and February because of too low variations of water-level. During other months, each investigation was made in six rectangles (3 per snail habitat), each measuring $2 \mathrm{~m}^{2}$ (length, $1 \mathrm{~m}$; width, $2 \mathrm{~m}$ ) and covering the five zones of the river bank. In these rectangles, snail counts were performed to determine three parameters: i) the total number of snails present in each rectangle, ii) that of snails in each zone of the rectangle, and iii) that of egg-deposits per rectangle. One hundred snails were also picked up in the most populated zone of the bank to measure their shell height under a stereomicroscope (snails were replaced in their zone after measures). The results obtained for each parameter during the three years were pooled and expressed for a single year. Mean values and S.D. were calculated for each parameter, taking into account the date of investigation (the four parameters) and the zone considered on the bank (parameter ii). A Kruskal-Wallis test and a two-way analysis of variance (Stat-Itcf 1988) were used to establish levels of significance.

\section{Behaviour of snails during water receding}

Fortnightly investigations were performed from March to December 2003 to determine if snails followed each day water receding. Snails measuring more than $5 \mathrm{~mm}$ in height were marked with red, waterproof points on the first whorls of shells and were placed in the zone corresponding to the highest water-level before daily receding. The parameters measured were i) the linear distance covered by snails during the daily retreat of water, ii) the time spent by snails to cover a distance of $40 \mathrm{~cm}$ (from the lowest zone of the habitat up to the highest zone when water rises) in July and Au- 
gust 2003, and iii) the shell height of these snails. Mean values and S.D. were determined for the parameter $i$, taking into account the date of investigation. The same calculation was done for the parameter ii and took into account snail height expressed in 1-mm classes. A Kruskal-Wallis test and a linear regression (Stat-Itcf 1988) were used to determine levels of significance.

\section{Changes in relation with low-water levels in summer}

Fortnightly records were made from July to November 2003 to specify survival rates of aestivating G. truncatula and those of snails which remained active during summer. The shell height of active snails moving only in the Z2-Z3 zones of their habitat (a total of 79 snails) and that of G. truncatula which followed each day water receding (20 snails) were also determined. Measurements were performed using a stereomicroscope equipped with an ocular micrometer.
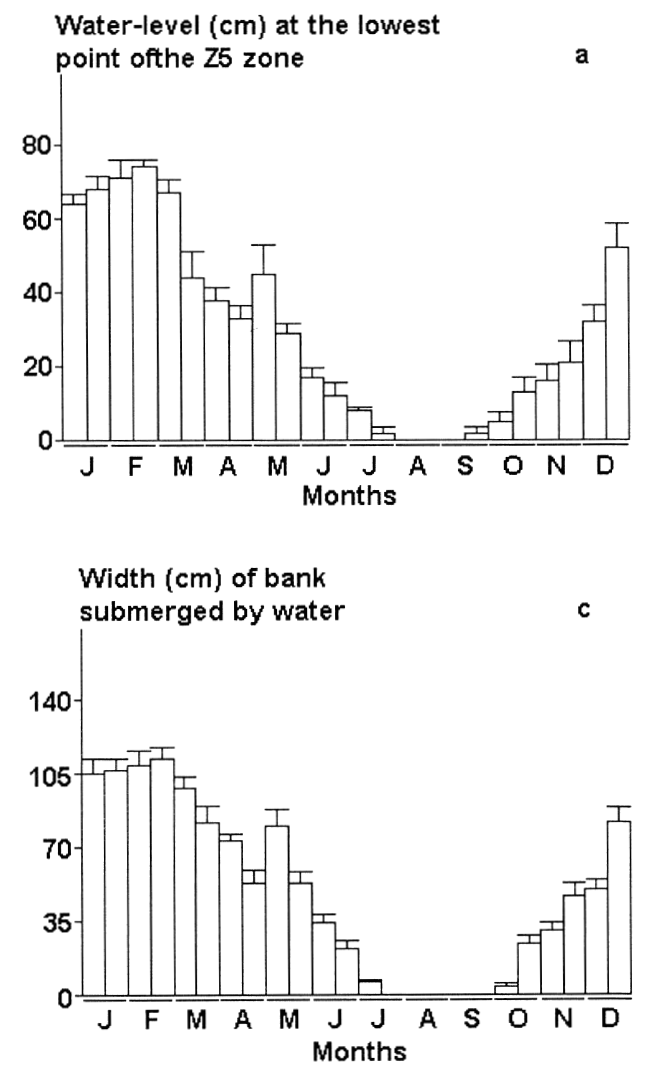

After measures, snails were put in the zone in which they were positioned. Individual shell heights were averaged and S.D. were established, taking into account the date of investigation. A logarithmic regression, a non-linear regression (survival rates) and a two-way analysis of variance (shell heights) were used to determine levels of significance.

A routine dissection of surviving snails was performed at mid-November 2003 to detect any trematode infection in both groups of $G$. truncatula.

\section{Results}

\section{Water-level variations throughout the year}

The decrease of water-level (Fig. 3) was less than 10 $\mathrm{cm}$ during winter months. In contrast, from July to September, the water fell every day from 28 to $35 \mathrm{~cm}$ (Fig. 3b), thus receding an emerged zone from 82 to $113 \mathrm{~cm}$ in width (Fig. 3d). The emersion of banks from water was effective for several hours per day (generally from 1 p.m. to 8 p.m.).
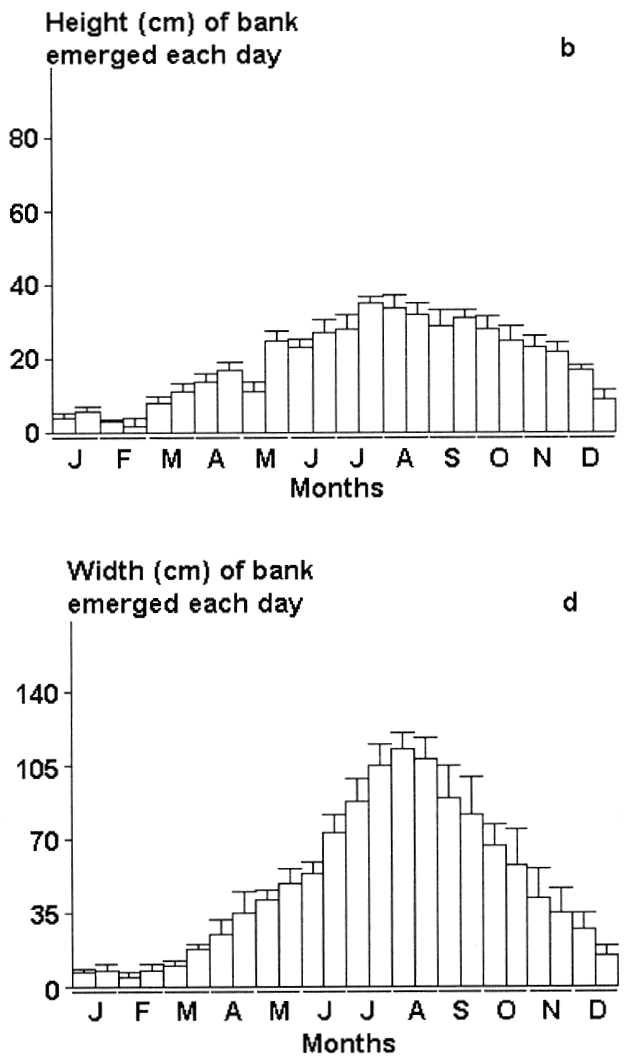

Fig. 3. Fortnightly variations of water-level measured on the bank of the Vienne river: the height of water layer at the lowest point of the Z5 zone (a), the height of the emerged zone (b), the width of the submerged bank (measured from the lowest point of the Z5 zone) (c), and the width of the emerged zone (d). 


\section{Distribution of snails in their habitat throughout the year}

Two significant variations $(H=75.51, P<0.001)$ in the number of snails per rectangle (Fig. 4 a) were noted between March and December. The first occurred from the end of June up to the beginning of September, with a peak at 237 snails $/ 2 \mathrm{~m}^{2}$ at the beginning of July. In spite of this high value, snail density fell from the end of July to the beginning of September, as the figures recorded during this last month ranged in the same scale of values than those noted in spring. The second variation was lower and occurred in December, with a peak at 73 snails $/ 2 \mathrm{~m}^{2}$ at the end of this month.

These two variations indicate the existence of two annual generations for $G$. truncatula and this finding is confirmed by the following facts. Firstly, the number of $\leq 2 \mathrm{~mm}$ snails (expressed in percentage in Fig. $4 \mathrm{~b}$ ) peaked at the beginning of July (at 75\%) and decreased afterwards up to September. A second peak $(31 \%)$ at the end of December was also noted. Secondly, the first period of egg-laying (Fig. 4c) started at the beginning of June and ended in July, with a peak (47 eggpackets $/ 2 \mathrm{~m}^{2}$ ) at the beginning of this month. Another period of egg-laying occurred in November-December, with a peak at the end of December (12 egg-packets $/ 2 \mathrm{~m}^{2}$ ). Significant variations throughout the year were found for the number of $\leq 2 \mathrm{~mm}$ snails $(H=$ 51.63, $P<0.001)$ and that of egg-packets $(H=26.46$, $P<0.001)$.

As great variations in the number of $G$. truncatula per rectangle (Fig. 4a) were noted throughout the year, the numbers of snails found in each zone of the rectangle are expressed in percentages (Fig. 5). The upper zone of each habitat (Z1) was only colonized by snails in March and at the beginning of April (Fig. 5a). Conversely, the section covered with G. fluitans (Z2) was inhabited all along the year. After the two peaks noted in April (82.6-83.8\%), the frequency of occupation steadily diminished until the end of July (at 5\%) and increased afterwards up to the end of December
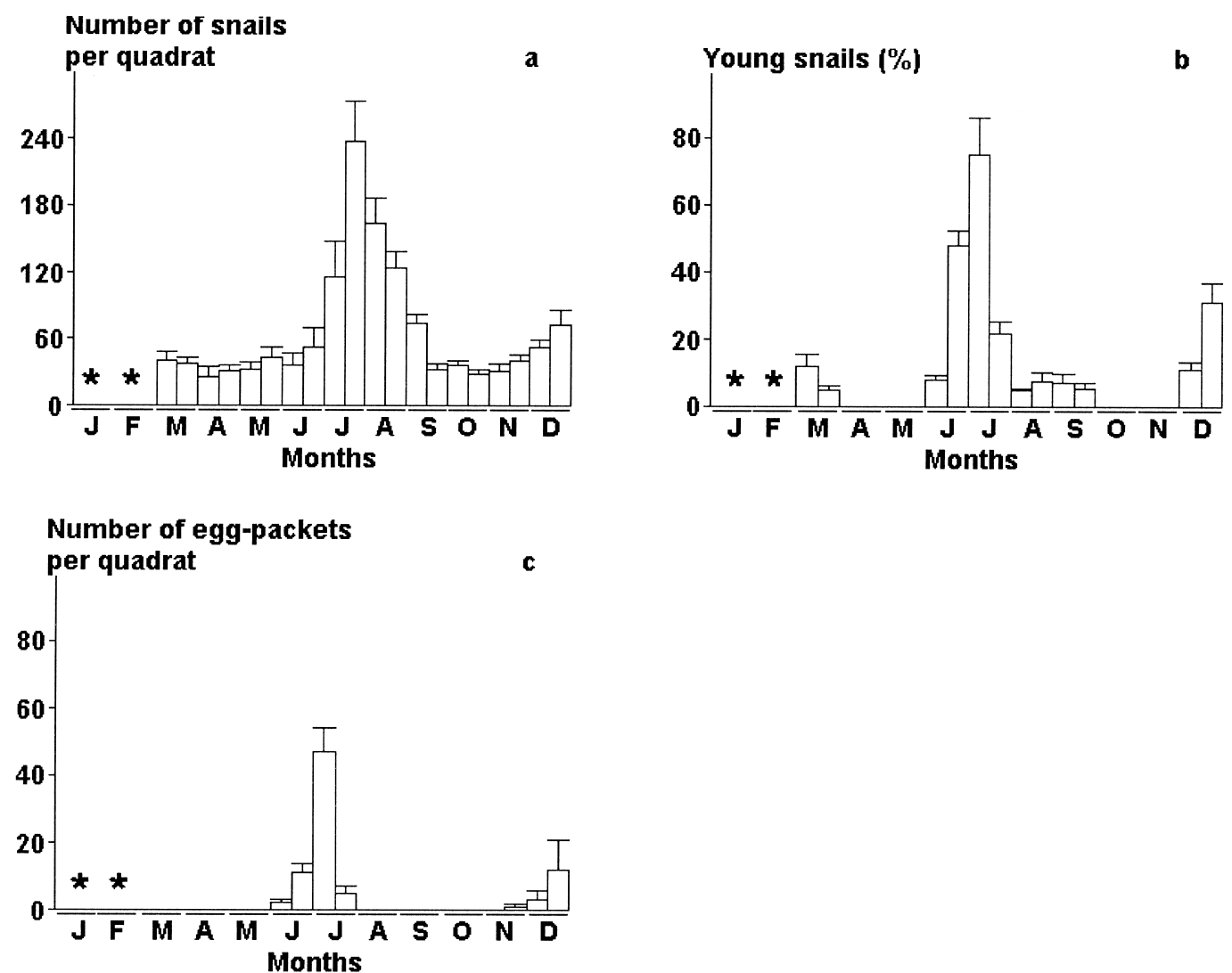

Fig. 4. Dynamics of Galba truncatula populations from March to December: the density of snails per rectangle (a), the number of young snails measuring $2 \mathrm{~mm}$ or less in height (b), expressed here in percentage, and that of egg-packets per rectangle (c). *, no record because of too low water-level variations. 
(Fig. 5b). The other three zones of each habitat were only colonized for a few months. Snails settled in the $\mathrm{Z} 3$ zone from April and the frequency increased up to the end of June (at $73.2 \%$ ) before a progressive decrease up to September and a later rise particularly marked in November and December (Fig. 5c). The frequency of snail distribution in the $\mathrm{Z} 4$ zone (Fig. 5d) increased from June to September (at 63.6\%) and lowered afterwards up to the end of November. The Z5 zone (data not shown) was only visited by several $G$. truncatula from July to October, so that percentages were less than $4 \%$. Significant influences for the date of investigation $(F=18.11, P<0.001)$ and the type of zone colonized by snails $(F=13.05, P<0.001)$ were noted.

\section{Behaviour of snails during water receding}

The linear distances covered by adult snails (Fig. 6a) were low enough from March to May and from November to December. Conversely, from July to September, they ranged from 25.4 to $44.3 \mathrm{~cm}$.
A significant difference $(H=83.10, P<0.001)$ between values found in July-September and those noted during the other months of the year was noted.

From March to the beginning of June and in November-December, snails were submerged by rising water and showed no flight reaction. In contrast, from the end of June to the end of October, snails preceded water rise by crawling up to still emerged zones of their habitat. Most of 5-mm high snails spent a mean of 5 min $32 \mathrm{~s}$ to cover $40 \mathrm{~cm}$ of wet, emerged bank and the mean time of this travel (Fig. 6b) significantly decreased (see table 1) with increasing shell height of snails. When the water reached its highest level, most snails stayed for 30 to $80 \mathrm{~min}$ on emerged ground before a new period of submersion in water.

\section{Changes in relation with low-water levels in summer}

Table 2 shows snail survival in the course of summer 2003. The survival rates of active snails significantly
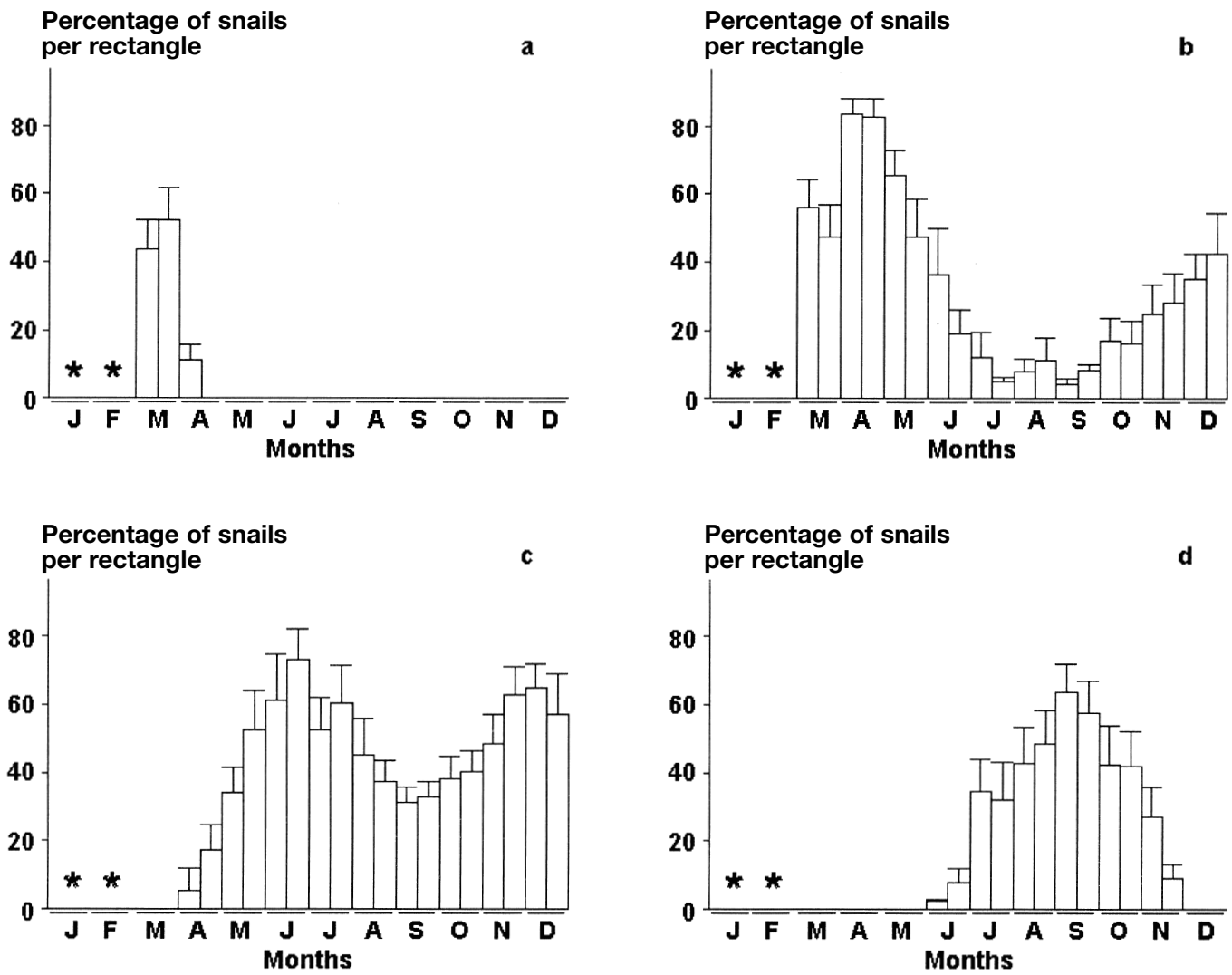

Fig. 5. Frequencies of snail distribution in the Z1 (a), Z2 (b), Z3 (c) and Z4 (d) zones from each rectangle throughout the year. *, no record because of too low water-level variations. 

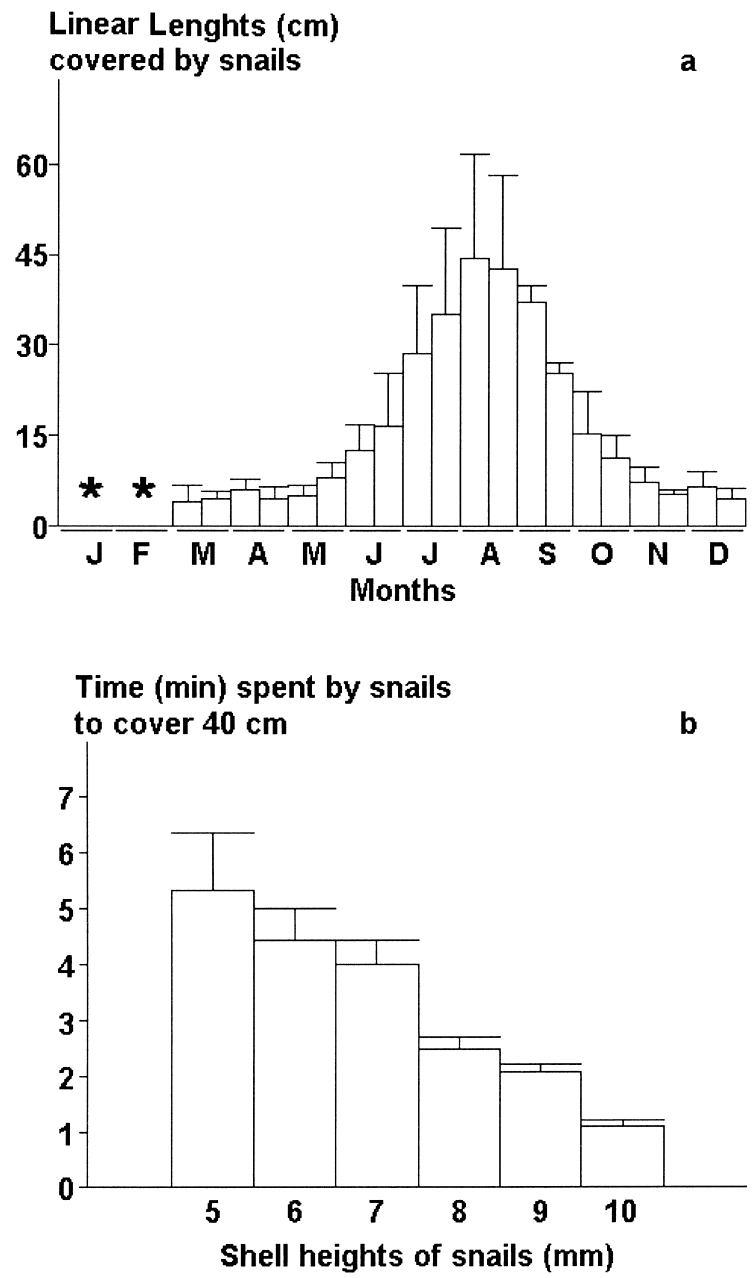

Fig. 6. The behaviour of snails on the river bank during the daily retreat of water: the linear distances covered by 286 snails measuring more than $5 \mathrm{~mm}$ in height from March to December 2003 (a) and the time spent by 171 adult snails to cover a distance of $40 \mathrm{~cm}$ on the emerged bank in July or in August 2003 (b). *, no record in reason of too low water-level variations.

decreased (see table 3) during the four months of low water-levels. Conversely, snails which aestivated on the substrate with their body withdrawn into their shell, had more chance to survive ( $17.1 \%$ of mortality only) and their rates were independent from record dates.

Figure 7 shows the shell heights of live G. truncatula which only moved in the Z2-Z3 zones and those of individuals which followed each day water receding. The growth of the former snails was limited until the

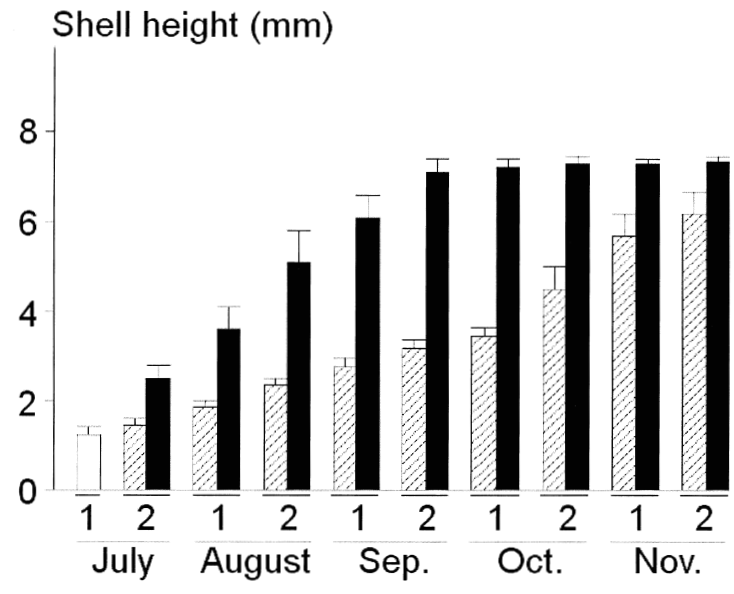

Fig. 7. The shell height of Galba truncatula from July to November 2003: i) snails only moving in the Z2-Z3 zones of their habitat (hachured squares) and ii) snails following each day water receding (dark squares). The results from both groups of snails were pooled at the beginning of July (open squares), as these young individuals originated from the same egg-deposits. Sep. (September). Oct. (October). Nov. (November).

beginning of October (their shell was only 3.4-mm high). The regular submersion of Z2-Z3 zones after this date induced a quicker growth of snails up to a mean of $6.2 \mathrm{~mm}$ at the end of November. Conversely, snails which followed each day water retreat showed a more regular growth of their shell and reached $7 \mathrm{~mm}$ at the end of September. Significant influences of snail group $(F=11.76, P<0.01)$ and the date of investigation $(F=16.45, P<0.001)$ were noted.

At the end of November, 20 G. truncatula following daily retreat of water were collected before being dissected. Twelve were infected with Haplometra cylindracea, while another snail harboured larval forms of an unidentified digenean species. In contrast, no snail infection was found in snails which moved only in the Z2-Z3 zones of their habitat.

Table 1. Linear regression results of times spent by 171 adult snails to cover $40 \mathrm{~cm}$ on the emerged bank (in July and August 2003) with the medium value of each shell height class. Equation used: $y=$ A. $\log 10 x+B$, with $x$ (medium value of snail height class) and $y$ (time spent by snails). $r$ (correlation coefficient).

\begin{tabular}{lcccc}
\hline Parameter & Value & S.D. & Value of t-test & Significance \\
\hline Slope A & -0.848 & 0.060 & 14.22 & $P<0.001$ \\
Intercept B & 9.600 & 0.460 & 20.89 & $P<0.001$ \\
r & 0.990 & - & - & $P<0.001$ \\
\hline
\end{tabular}


Table 2. Distribution of Galba truncatula on river banks during lowwater levels in simmer in relation to their activity and their physiologic state. The results recorded in November 2003 are not given because of the death of numerous adult snails during this month. *, aestivating snails.

\begin{tabular}{|c|c|c|c|c|}
\hline \multirow{2}{*}{$\begin{array}{l}\text { Dates of records } \\
(2003)\end{array}$} & \multirow{2}{*}{$\begin{array}{c}\text { Total number of } \\
\text { snails }\end{array}$} & \multicolumn{2}{|c|}{ Number of snails (\%) } & \multirow{2}{*}{$\begin{array}{c}\text { Mortality rate } \\
(\%)\end{array}$} \\
\hline & & In activity & $\begin{array}{l}\text { Settled and } \\
\text { alive * }\end{array}$ & \\
\hline July 10 & 402 & $283(70.3)$ & $52(12.7)$ & 17.0 \\
\hline July 22 & 678 & $390(57.5)$ & $172(25.3)$ & 17.2 \\
\hline August 11 & 435 & 193 (44.4) & $84(19.2)$ & 36.4 \\
\hline August 22 & 511 & $185(36.2)$ & $73(14.3)$ & 49.5 \\
\hline September 10 & 241 & $71(29.2)$ & $29(11.7)$ & 59.1 \\
\hline September 21 & 178 & $40(22.3)$ & $19(10.2)$ & 68.5 \\
\hline October 10 & 154 & $29(18.4)$ & $14(9.1)$ & 72.5 \\
\hline October 21 & 137 & $21(15.2)$ & $12(8.2)$ & 76.6 \\
\hline
\end{tabular}

Table 3. Logarithmic regression results of survival rates for snails remaining active during summer 2003 with the date of record. Equation used: $\mathrm{y}=\mathrm{D} /[1+\exp (-\mathrm{A} \cdot \mathrm{x}+\mathrm{B})]$, with $\mathrm{x}$ (date of records) and $\mathrm{y}$ (snail survival). $\mathrm{r}$ (correlation coefficient).

\begin{tabular}{lcccc} 
Parameter & Value & S.D. & Value of t-test & Significance \\
\hline $\mathrm{D}$ & 0.789 & 0.028 & 27.72 & $P<0.001$ \\
$\mathrm{~A}$ & 0.044 & 0.005 & 7.61 & $P<0.001$ \\
$\mathrm{~B}$ & 1732.609 & 227.502 & 7.61 & $P<0.001$ \\
$\mathrm{r}$ & 0.993 & - & - & $P<0.001$ \\
\hline
\end{tabular}

\section{Discussion}

Snails from both populations, Vienne river and Taurion river, followed seasonal variations of water-level but only a few of them were observed following the daily retreat of water. This behaviour agreed with the reports of some authors (see review by Taylor 1965) in other habitats of $G$. truncatula, as those located at the periphery of an open drainage network in swampy meadows. Owing to the presence of G. fluitans, the Z2 zone must be considered as the permanent area of each habitat (Taylor 1965), while Z3 to Z5 zones were temporarily colonized for several months. To explain this last result, one reason might be the research of food by snails on the different zones, as blue and/or green unicellular algae, generally eaten by snails (Kendall 1953), seemed scarce on river banks and did not form the algal carpet which can be observed in spring in the other types of $G$. truncatula habitats. The presence of several snails, which followed each day water retreat, particularly from July to November, was more difficult to comment, as the research of food was not probably the single reason of this behaviour. As most snails were infected with larval forms of digenea, one may put forward the necessity of a permanent contact of snails with water to explain their behaviour, as snails infected with the parasite Fasciola hepatica were less amphibious and more dependent on water than uninfected controls (Rondelaud 1974).

The fact that two generations of $G$. truncatula follo- wed one another throughout the year agreed with the observations performed in other snail habitats, located in western Europe (Kendall 1953, Heppleston 1972, Morel-Vareille 1973, Smith 1981) or in North Africa (Goumghar et al. 2001; Mekroud et al. 2002). However, in the case of river banks on acid soil, a difference between the results of the present study and those reported by Vareille-Morel et al. (1998) can be noted, as these last authors noted a single annual generation of G. truncatula in habitats located on the banks of the Creuse and Vienne rivers, with egg-laying in July and at the beginning of August. In our opinion, the presence of a second snail generation in the habitats of Saint Priest Taurion may only be explained by the existence of the daily retreat of water in these two places: this process would favour the growth of several snails (see Fig. 7) and would allow the deposit of a few egg-packets from mid-November when water submerged again the $\mathrm{Z} 2$ zone. An argument supporting this interpretation was the few number of egg-packets at the end of December (12 per rectangle, Fig. 4c), whereas the mean number of snails per rectangle from the end of September to November was similar to that noted from March to June (28 to 41 snails per rectangle, Fig. 4a).

The distances covered by several snails from July to September when water recedes each day (25.4 to 44.3 $\mathrm{cm}$ ) and the times spent to cover $40 \mathrm{~cm}$ of bank (a mean of $5 \mathrm{~min} 30 \mathrm{~s}$ for 5-mm high snails) allowed to suggest that populations of $G$. truncatula living along river banks would be completely adapted to their habitats. In spite of this capacity, one may wonder about flight that snails effected each day from July and October when water rises again, whereas these snails did not show such reaction during other months of the year. Similar flight reactions have already been reported for G. truncatula when this snail found a predator: it sought refuge into water when the aggressor was a land species, or crawled up to the emerged zones of its habitat in the case of a freshwater predator (Rondelaud 1978). However, even if several predators were seen in snail habitats along river banks, their presence did not explain the daily escape of snails when water rose again, so that another cause must be proposed to explain this process. As snails have been reported to quickly exit from water under laboratory conditions when the water-level rapidly increases (Kendall 1953, Moens 1991), the more likely hypothesis would be to consider the escape of snails on river banks as a physiological reaction of survival towards a too rapid increase of water-level, especially in the Z4 and Z5 zones (see Fig. 2) which are clearly flatter than the other zones of snail habitats. 


\section{References}

Burt N. \& Watts J. 1996. - Barrages: engineering, design and environmental impacts. John Wiley \& Sons Ltd, Chichester New York Brisbane, $516 \mathrm{p}$.

Dreyfuss G., Vareille-Morel C. \& Rondelaud D. 1997. - Les habitats de Lymnaea truncatula Müller (Mollusque) le long de deux rivières. Ann. Limnol., 33, 67-72.

Goumghar M.D., Vignoles P., Rondelaud D., Dreyfuss G. \& Benlemlih M. 2001. - Relations entre les générations annuelles de Lymnaea truncatula (Mollusca Gastropoda: Lymnaeidae), l'altitude et la nature de ses habitats dans le centre du Maroc. Rev. Med. Vet. (Toul.), 152, 457-462.

Heppleston P.B. 1972. - Life history and population fluctuations of Lymnaea truncatula Müller, the snail vector of fascioliasis. J. Appl. Ecol., 9, 235-248.

Kendall S.B. 1953. - The life-history of Limnaea truncatula under laboratory conditions. J. Helminthol., 27, 17-28.

Mekroud A., Benakhla A., Benlatreche C., Rondelaud D. \& Dreyfuss G. 2002. - First studies on the habitats of Galba truncatula (Mollusca Gastropoda: Lymnaeidae), the snail host of Fasciola hepatica, and the dynamics of snail populations in northeastern Algeria. Rev. Med. Vet. (Toul.), 153, 181-188.
Moens, R. 1991. - Factors affecting Lymnaea truncatula populations and related control measures. J. Med. Appl. Malacol., 3, 73-84.

Morel-Vareille C. 1973. - Contribution à l'étude du cycle biologique de Lymnaea truncatula dans le nord-ouest du Limousin. Rev. Med. Vet. (Toul.), 124, 1447-1457.

Rondelaud D. 1974. - Le cycle d'activité journalier de Galba truncatula Müller et sa relation avec le parasitisme. Ann. Parasitol. Hum. Сотр., 49, 427-434.

Rondelaud D. 1978. - Le comportement des Limnées tronquées (Lymnaea (Galba) truncatula Müller) saines ou infestées par Fasciola hepatica L. en présence de leurs prédateurs. Ann. Parasitol. Hum. Comp., 53, 63-74.

Smith G. 1981. - A three-year study of Lymnaea truncatula habitats, disease foci of fascioliasis. Br. Vet. J., 17, 329-342.

Stat-Itcf. 1988. - Manuel d'utilisation. Institut technique des céréales et des fourrages, Service des études statistiques, Boigneville, $210 \mathrm{p}$.

Taylor E.L. 1965. - Fascioliasis and the liver-fluke. FAO Agricultural Studies, Roma, $n^{\circ} 64,235$ p.

Vareille-Morel C., Rondelaud D. \& Dreyfuss G. 1998. - Galba truncatula (Gastropoda, Lymnaeidae): preliminary findings on the ecology and ethology of populations living along river banks. Haliotis, 27, 35-42. 